\title{
Completely self-assembled fiber composites
}

\author{
Elizabeth C. Claunch, Devin M. Ridgley, and Justin R. Barone
}

Biological Systems Engineering Department and Macromolecules and Interfaces Institute, Virginia Tech, 301D HABB1, Blacksburg, VA 24061, USA

TITLE RUNNING HEAD: Self-assembled fiber composites

* To whom correspondence should be addressed. E-mail: jbarone@vt.edu. Phone: (540) 2310680.

\begin{abstract}
Wheat gluten is hydrolyzed to low molecular weight proteins where some of the proteins self-assemble into high modulus fibers and the rest arrange around the fibers to form a polymer matrix so that the total material produces a fiber-reinforced polymer matrix composite. Selfassembly at $37^{\circ} \mathrm{C}$ yields fiber composites with a modulus of $266 \mathrm{MPa}$. Self-assembly at $22^{\circ} \mathrm{C}$ suppresses fiber formation resulting in polymer materials of much lower $20 \mathrm{MPa}$ modulus. Fourier transform infrared (FTIR) spectroscopy results show both materials have similar $\beta$-sheet content of about $50 \%$ but the composites formed at $37^{\circ} \mathrm{C}$ have increased hydrogen bonding. Hydrophobic interactions are also different in the $37^{\circ} \mathrm{C}$ composite because it is hydrophobic interactions that drive self-assembly into large amyloid fibers. Scanning electron microscopy (SEM) shows that there is good interaction between the fiber and matrix because protein completely coats the fibers and no voids are observed at the fiber/polymer interface. Thermogravimetric analysis (TGA) shows that the $37^{\circ} \mathrm{C}$ composite is more thermally stable at higher temperatures because of the increased intermolecular interactions and the presence of fibers.
\end{abstract}

Keywords: A. Polymer-matrix composite, B. Mechanical properties, B. Thermal properties, D. Infrared (IR) spectroscopy, D. Scanning electron microscopy (SEM) 


\section{Introduction}

A fiber-reinforced polymer composite consists of a continuous polymer matrix phase and a discontinuous fiber reinforcement phase. The matrix phase is usually present in higher volume fraction than the reinforcement phase although recent advances in composites, particularly with biobased fiber reinforcement, have used very high fiber contents [1,2]. In a typical polymer composite, the matrix is of low density and high toughness and the reinforcement is of higher density but high rigidity and strength. Combining the materials results in a composite that is more rigid and strong than the polymer itself and less dense and tougher than the reinforcement itself. Fibers can be short or long. Short fibers are amenable to mixing with the polymeric matrix on an extruder, making processing easier. Short fibers usually randomly orient in the matrix, unless the processing dictates otherwise, giving isotropic composite properties. Long fibers can be oriented in any direction to make anisotropic composites but cannot be processed on high volume equipment like extruders. Typical commercial fiber reinforcements include carbon and glass. Glass is economical but dense and carbon fiber vice versa. Glass and carbon are hydrophilic and most often are mixed with hydrophobic synthetic polymers like polyolefins or epoxy to form a composite. Usually, a third component called a "compatibilizer" must be used to increase interactions between the fiber and polymer and yield a good fiber/polymer interface for efficient load transfer during use [3-9]. Neither carbon nor glass is considered sustainable and thus there has been interest in using natural fibers to reinforce polymer composites because they are of low density and high stiffness $[6,10,11]$.

Traditional attempts to make more sustainable composites involve mixing natural fibers of lignocellulose or protein in a polymer matrix, which can be synthetic or biobased $[6,12,13]$. A lot of biopolymer matrices have poor mechanical properties and are prone to moisture absorption 
so forming a composite can improve mechanical properties and moisture resistance [12, 14-16]. Natural fibers can vary in properties depending on how they are grown, which is not a problem with synthetic fibers $[6,17]$. Protein-based fiber composites have been studied including using poultry feather fiber as the reinforcing phase in polyolefin matrices and using lignocellulosic fibers in plasticized keratin, soy protein, or wheat gluten matrices $[10,11,18-20]$. Wheat gluten (WG) is an interesting natural material because of its abundance, low cost, good biodegradability, and non-toxicity $[8,14,21,22]$. Wheat gluten has good viscoelastic properties, reasonable tensile strength, is an excellent $\mathrm{O}_{2}$ and $\mathrm{CO}_{2}$ gas barrier, and has the ability to fully degrade in less than 50 days $[14,21,23,24]$. It is found that reinforcement with natural fibers significantly improves the mechanical properties of wheat gluten [17]. There are examples in the literature of wheat gluten being reinforced with a variety of natural fibers and fillers such as coconut fiber, hydroxyethyl cellulose, jute, nanoclay particles, hemp, and basalt $[8,14,16,17$, 21-24]. Care has to be taken during the processing of temperature sensitive natural fibers and biopolymers to avoid degradation $[6,25]$. For this reason, the thermal processing used in synthetic composite manufacture may not be suitable for biobased composites $[15,17]$. WG has been processed using extrusion, compression molding, and solution casting but protein molecular weight decrease as a result of thermal degradation or solvent-induced hydrolysis can decrease mechanical properties $[16,17,24]$.

Most fiber-reinforced polymer composites are considered "macrocomposites" by today's standards because the fibers have a diameter, $\mathrm{D}$, of 10-150 $\mu \mathrm{m}$ [3]. Nanocomposites are formed from nanometer-sized reinforcements and the typical one is nanoclay [26]. There is an emerging nanomaterial called an "amyloid" that exists as protofibrils $\sim 2-4 \mathrm{~nm}$ high, 10-30 nm wide, and micrometers to millimeters long [27]. Amyloids are formed from the self-assembly of protein 
molecules [28-30]. Proteins unravel, straighten, and hydrogen bond to a nearby straightened protein to form a $\beta$-sheet. $\beta$-sheets can stack on top of one another and protein molecules can continue to add onto the ends of the growing $\beta$-sheets, elongating them into protofibrils where the $\beta$-sheets are oriented perpendicular to the protofibril axis [31]. While amyloids have been mostly studied in the context of neurodegenerative diseases, "functional" amyloids used to protect and proliferate life are a burgeoning field of study [32,33]. Functional amyloids include barnacle cement and fibrous hyphae used by bacteria and fungi to form biofilms and attach to surfaces $[34,35]$. The amyloid protofibril phase in these materials confers large increases in rigidity and toughness. Many different proteins have been shown to form amyloid fibrils [32]. Typical amyloid fibrils from a variety of proteins have moduli, E, of 2-4 GPa [36, 37]. The fibril modulus is related to how much protein incorporates into the $\beta$-sheet [38]. Optimizing selfassembly conditions to incorporate more protein into $\beta$-sheets can yield amyloids with moduli higher than spider silk, i.e., E 20-50 GPa [27]. Thus, there is substantial interest in producing amyloids for engineered materials like films, adhesives, and composites [39]. There are multiple research studies on using the nanometer-sized amyloid fibrils for nanocomposites. Some reports utilize the amyloid to produce "smart" nanocomposites that perform functions beyond load bearing or in specialized biomedical applications [40-42]. Others simply use the nanometer amyloid fibrils to provide reinforcement of commodity polymers such as cross-linked polydimethyl siloxane (PDMS) [43]. A $2 \mathrm{wt} \%$ amyloid nanocomposite shows equal reinforcement to a $2 \mathrm{wt} \%$ carbon nanotube (CNT) nanocomposite and both are about $50 \%$ higher in strength than the PDMS by itself. Increasing the amyloid content to $10 \mathrm{wt} \%$ and orienting the protofibrils along the deformation axis during testing results in a nanocomposite with 3 times the modulus of a $10 \mathrm{wt} \% \mathrm{CNT}$ nanocomposite, which is still about $50 \%$ higher in modulus than the 
PDMS by itself. All of the nanocomposites maintain the $40 \%$ strain to break of the PDMS matrix, which is a good indication that the polymer matrix impact resistance is not degraded upon nanocomposite formation. Another report describes the lysozyme amyloid protofibril reinforcement of polylactic acid (PLA) at 1-5 wt $\%$ amyloid [44]. Modulus and strain to break increase dramatically as a function of amyloid content in the nanocomposites compared to the PLA matrix by itself with no change in breaking strength. It is found that the nanocomposites have higher glass transition temperature $\left(\mathrm{T}_{\mathrm{g}}\right)$ but lower crystallinity. The amyloid suppresses crystallinity in the PLA phase and thus increases strain to break. As crystallinity is lost, load transfer is assumed by the amyloid protofibrils so the modulus increases and breaking strength is maintained. Insulin amyloid protofibrils have been added to aqueous polyvinyl alcohol (PVOH) solutions and then the water evaporated. The resulting $0.6 \mathrm{wt} \%$ amyloid-PVOH nanocomposites are $15 \%$ stiffer than $\mathrm{PVOH}$ alone and again the PVOH crystallinity is suppressed with the addition of the amyloid [45].

It has been shown that self-assembly can continue beyond the protofibril stage all the way to the micrometer scale [46-52]. The final fibers are called "large amyloid fibers" with $\mathrm{D}=10-20$ $\mu \mathrm{m}$ and are similar in morphology and properties to natural protein fibers like silk. The key to hierarchical self-assembly of large amyloid fibers is to create mixtures of "template" and "adder" proteins that work cooperatively to overcome free energy barriers to self-assembly and allow protofibrils to further bundle into larger and larger structures. A very important feature of the "template and adder" process is that changing the adder protein sends the self-assembly down a different path resulting in large amyloid fibers of different shape, structure, and properties, which is related to the hydrophobicity and glutamine content of the adder protein. Hydrolysis of wheat gluten results in a mixture of template and adder proteins where the adder proteins have high 
glutamine (Q) content and produce compact protofibrils and round large amyloid fibers of $\mathrm{E}=2.5$ $\mathrm{GPa}[47]$.

Here, trypsin hydrolyzed wheat gluten produces lower molecular weight proteins where some proteins self-assemble into high rigidity large amyloid fibers and the rest arrange around the fibers to form a polymer matrix to produce a fully self-assembled fiber composite. Thus, this is the first report of fully self-assembled amyloid macrocomposites. It is hypothesized that a fully self-assembled fiber composite can overcome a lot of the problems of traditional sustainable biobased composites because: 1) a perfect interface exists in a self-reinforced composite because the fiber and matrix are made of the same material, 2) low temperature processing in water will not degrade the material, 3) self-assembled protein fibers can be produced in vitro with the same properties over and over again, 4) the composites would be of low density, and 5) the composites would mimic naturally-occurring composites formed through self-assembly processes, which have extraordinary strength, stiffness, and toughness [53]. In this study, self-assembled wheat gluten composites are formed and then characterized with 3-point bend (3PB) mechanical testing, scanning electron microscopy (SEM), Fourier transform infrared (FTIR) spectroscopy, and thermogravimetric analysis (TGA).

\section{Materials and methods}

\subsection{Hydrolyzed wheat gluten (WG)}

Two solutions were prepared by dissolving $4 \mathrm{~g}$ of wheat gluten (MP Biomedicals, LLC, Solon, $\mathrm{OH}$ ) in $160 \mathrm{ml}$ of pure water and hydrolyzing with $60 \mathrm{mg}$ of trypsin (Type I from bovine pancreas, Sigma-Aldrich, St. Louis, MO) at a 1:67 enzyme to substrate ratio (w/w). The solutions were maintained at $37^{\circ} \mathrm{C}$ and $\mathrm{pH} 8$ with $1 \mathrm{M} \mathrm{NaOH}$ for 24 hours to hydrolyze the protein. The molecular composition of the hydrolysate has been characterized with fast protein 
liquid chromatography (FPLC) and sodium dodecyl sulfate-polyacrylamide gel electrophoresis (SDS-PAGE) [54].

\subsection{Formation of composite}

After hydrolysis, one solution was maintained at $37^{\circ} \mathrm{C}$ and the other maintained at $22^{\circ} \mathrm{C}$. The solutions were pipetted into rectangular $30 \mathrm{~mm}$ long x $6 \mathrm{~mm}$ wide x $6 \mathrm{~mm}$ thick silicone molds and then allowed to dry under a fume hood until the water level decreased significantly such that more solution could be pipetted in. This process was continued for about 20 days to yield sufficient solid material in the mold to produce a rectangular bar. It has been shown that there is robust fiber formation over 20 days at $37^{\circ} \mathrm{C}$ while fiber formation is suppressed over the same time at $22^{\circ} \mathrm{C}[48]$. Once all the water was visibly gone the samples were transferred to an incubator and completely dried at $37^{\circ} \mathrm{C}$ for 10 days to remove excess water. The resulting sample thicknesses were $2.5-4.0 \mathrm{~mm}$.

\subsection{Mechanical testing}

3 point bending (3PB) was performed according to ASTM D790, which has been used for other wheat gluten composites $[7,8,15,23]$. 3PB testing was performed on a TA.HDplus (Stable Micro Systems, Surrey, UK) mechanical tester equipped with a $100 \mathrm{~kg}$ load cell using a crosshead speed of $1 \mathrm{~mm} / \mathrm{min}$. 3PB grips were positioned to give a span of $24 \mathrm{~mm}$ to yield span/sample thickness ratios of 6.0-9.6. Flexural stress and strain, $\sigma$ and $\varepsilon$, respectively, were calculated according to ASTM D790. Flexural modulus (or "modulus"), E, was calculated from the linear region after correcting for the toe region. Flexural stress at break and strain at break, $\sigma_{b}$ and $\varepsilon$ b, respectively, were taken as the point of visible sample breakage and rapid decline in measured force. 8 samples at each condition were tested and averages \pm standard errors reported. 


\subsection{Fourier transform infrared (FTIR) spectroscopy}

Composites were dried overnight under vacuum. Attenuated total reflectance (ATR) FTIR spectra of the composites were recorded on a Thermo Nicolet 6700 FTIR Spectrometer (Thermo Fisher Scientific Inc., Madison, WI). Samples were loaded into a Smart Orbit ATR diamond crystal and spectra acquired with 256 scans at $4 \mathrm{~cm}^{-1}$ resolution from $4000-525 \mathrm{~cm}^{-1}$ with a blank background. Deconvolution of the Amide I absorbance to analyze protein secondary structure content was performed using a standard protocol [50]. To find the absorbance area around 3250 $\mathrm{cm}^{-1}$, the absorbance maximum was normalized to 1 and then the area calculated using OMNIC v8.1 so that all spectra could be compared without effects from absorbance intensity differences during the experiment. Values are reported as averages \pm standard error.

\subsection{Scanning electron microscopy (SEM)}

Fractured 3 point bend samples were dried overnight under vacuum to remove excess water. Fractured specimens, with the fracture surface pointing up, were mounted onto aluminum SEM stubs with double-sided tape. Scanning electron micrographs of the fracture surface and sample edges were obtained using a LEO 1550 field-emission SEM (Zeiss, Peabody, MA) with a 4-6 $\mathrm{mm}$ working distance, $5 \mathrm{kV}$ accelerating voltage, and an In-lens SE-detector. Fiber dimensions and volume fractions were extracted from these images using ImageJ v1.46r.

\subsection{Thermogravimetric analysis (TGA)}

TGA was performed on a TA Instruments SDT Q600 (New Castle, DE). 4-6 mg samples were heated at $10^{\circ} \mathrm{C} / \mathrm{min}$ from room temperature to $600^{\circ} \mathrm{C}$ in a nitrogen atmosphere. Nitrogen flow rate was $100 \mathrm{~mL} / \mathrm{min}$. Samples were run in duplicate and representative weight loss versus temperature and first derivative of weight loss with temperature (dTGA) versus temperature data reported. 


\section{Results and discussion}

It has been shown that incubating the trypsin hydrolyzed wheat gluten solution at $37^{\circ} \mathrm{C}$ results in a lot of self-assembled WG fibers of $2.5 \mathrm{GPa}$ modulus while incubating at $22^{\circ} \mathrm{C}$ inhibits fiber formation $[47,48]$. SEM examination of $3 \mathrm{~PB}$ samples shows that the $37^{\circ} \mathrm{C}$ sample yields a lot more fibers than the $22^{\circ} \mathrm{C}$ solution (Fig. 1 and Fig. 2a,b). SEM images are analyzed by counting the number of fibers in a given area and dividing by the area. More fibers are found in larger areas so taking the inverse yields the total area per fiber found, $\mathrm{A}_{\mathrm{T}}\left(\mu \mathrm{m}^{2} /\right.$ fiber). It is typically easier to find fibers on the sample edges (Fig. 2a,b) than in the fracture surface (Fig. $2 \mathrm{c}, \mathrm{d})$ because of the lack of topography. The $37^{\circ} \mathrm{C}$ solution yields a fiber-reinforced composite while the $22^{\circ} \mathrm{C}$ solution acts as a control with properties approximately those of the WG polymer matrix. Good compatibility between the fiber and matrix is observed (Fig. 2d). There are no voids at the fiber/polymer interface and the fibers are well coated by polymer matrix. Uncoated fibers have the same dimensions as individual fibers found without composite formation with diameter, $\mathrm{D}=10-15 \mu \mathrm{m}$, and the characteristic surface roughness of WG fibers (Fig. 3). WG fibers formed at this condition are typically $0.5-1.5 \mathrm{~mm}$ long so the self-assembled composites are short fiber reinforced polymer composites [47].

The modulus and flexural stress at break of the $37^{\circ} \mathrm{C}$ composites are much higher than the $22^{\circ} \mathrm{C}$ materials (Table I and Fig. 4a,b). Flexural strain at break decreases slightly for the higher fiber content $37^{\circ} \mathrm{C}$ composite, which is typical of fiber reinforced polymer composites [18]. The $22^{\circ} \mathrm{C}$ material displays a more ductile fracture mode as observed by the fracture surface (Fig. 2c) while the $37^{\circ} \mathrm{C}$ composite displays more brittle failure (Fig. 2d), which is consistent with the lower average flexural strain at break. Properties are plotted as a function of fiber volume 
fraction, $\phi_{\mathrm{f}}$, measured from the SEM images using the average area per fiber, $\mathrm{A}_{\mathrm{T}}$, and assuming a constant layer thickness

$$
\phi_{\mathrm{f}}=\mathrm{V}_{\mathrm{f}} / \mathrm{V}_{\mathrm{T}}=\mathrm{A}_{\mathrm{f}} / \mathrm{A}_{\mathrm{T}}
$$

(Equation 1)

where $V$ is volume, $A$ is area, $f$ and $T$ denote fiber and total, respectively, and $A_{f}=\pi D^{2} / 4$. Comparisons are made on equal areas to avoid overestimation of the number of fibers from comparing too many high magnification images in one sample over the other.

The properties of the composites are fit to a simple rule of mixtures model

$$
\begin{aligned}
& E=\phi_{\mathrm{f}} \mathrm{E}_{\mathrm{f}}+\phi_{\mathrm{m}} \mathrm{E}_{\mathrm{m}} \\
& \sigma_{\mathrm{b}}=\phi_{\mathrm{f}} \sigma_{\mathrm{fb}}+\phi_{\mathrm{m}} \sigma_{\mathrm{mb}}
\end{aligned}
$$

where $\mathrm{f}$ and $\mathrm{m}$ denote fiber and matrix, respectively, and $\phi_{\mathrm{m}}=1-\phi_{\mathrm{f}}$. These equations assume perfect adhesion between the fiber and matrix. The properties of the matrix, $\mathrm{E}_{\mathrm{m}}$ and $\sigma_{\mathrm{mb}}$, are taken as those measured at $22^{\circ} \mathrm{C}$ because there are very few fibers found at that condition. Fitting the $\mathrm{E}$ and $\sigma_{\mathrm{b}}$ data to Equations $2 \mathrm{a}, \mathrm{b}$ results in $\mathrm{E}_{\mathrm{f}}=120,000 \mathrm{MPa}$ and $\sigma_{\mathrm{fb}}=2000 \mathrm{MPa}$. Using nanoindentation, the modulus of individual WG fibers made at $\mathrm{pH} 8$ and $37^{\circ} \mathrm{C}$ has been measured to be $2500 \mathrm{MPa}$ [47]. It is believed that the discrepancy arises partly from underestimation of $\phi_{\mathrm{f}}$ from SEM data. Using $\mathrm{E}_{\mathrm{f}}=2500 \mathrm{MPa}$ in Equation 2a and fitting $\phi_{\mathrm{f}}$ results in the values depicted on the top $\mathrm{x}$-axis in Fig. $4 \mathrm{a}$ with $\phi_{\mathrm{f}}=0.1$ for the $37^{\circ} \mathrm{C}$ composite. There are typically more fibers observed on the edge than on the fracture surface, although both are used in the calculation of Ат. When viewing the sample edge such as depicted in Fig. 2a,b, the fibers protrude from the surface and are easy to see. Although there are more measured fibers at $37^{\circ} \mathrm{C}$ than $22^{\circ} \mathrm{C}$, the fibers are heavily coated with matrix and hard to find (Fig. 5a,b), which could contribute to underestimation of $\phi_{f}$. In some cases holes approximately equal to the fiber diameter are observed (Fig. 5c), which could be fiber pull out during fracture where the fibers 
would be observed in the other half of the fracture surface. The fiber in Fig. $2 d$ pulled out of the matrix during failure instead of breaking in the fracture plane. This fiber is not heavily coated with matrix material and there is only a short amount of fiber extending from the surface. It may be that fibers with their ends near the fracture plane may show localized debonding rather than breaking. This may also contribute to underestimation of $\phi$ f. However, the fiber protruding from the fracture plane in Fig. $5 \mathrm{~b}$ is heavily coated with matrix material, suggesting failure occurred in the matrix phase near the fiber/matrix interface. Indeed, the material around the hole observed in Fig. $5 \mathrm{c}$ is drawn out from the fracture plane, which indicates that the matrix deformed near the fiber/matrix interface.

Although the $22^{\circ} \mathrm{C}$ and $37^{\circ} \mathrm{C}$ materials are made from the same chemically similar WG solution, the resulting materials are quite different because of the different self-assembly conditions. FTIR analysis shows that the samples are structurally different and that the same proteins assume different types of interactions in each material. Deconvolution of the Amide I absorbance in the FTIR spectrum allows for the calculation of the $\beta$-sheet mole fraction of each material [50]. Amyloids contain $\beta$-sheets and the $\beta$-sheet content is an important factor influencing rigidity and strength of protein materials $[27,38,55,56]$. Deconvolution shows that both the $22^{\circ} \mathrm{C}$ and $37^{\circ} \mathrm{C}$ materials have a similar $\beta$-sheet content of about $50 \%$. At $37^{\circ} \mathrm{C}$, proteins can add into nucleating $\beta$-sheets and elongate them to hierarchically produce large amyloid fibers from protofibrils [49]. $\beta$-sheets are still formed at $22^{\circ} \mathrm{C}$ but sluggish kinetics at lower temperature mean $\beta$-sheets cannot sufficiently elongate to produce protofibrils $[57,58]$.

Although the $\beta$-sheet content is similar in both materials, the properties are quite different. In the $37^{\circ} \mathrm{C}$ composite, some of the $\beta$-sheets exist in a fibrous form, imparting stiffness and strength to the material. 
The state of the protein molecules in the $37^{\circ} \mathrm{C}$ composite appears different from the $22^{\circ} \mathrm{C}$ material as determined by FTIR spectroscopy. Analysis of FTIR absorbances are summarized in Table II $[47,48,50]$. The absorbance at $1080 \mathrm{~cm}^{-1}$ is assigned to the $\mathrm{CN}$ stretching absorbance, $v(\mathrm{CN})$, and the absorbance at $1016 \mathrm{~cm}^{-1}$ is assigned to the $\mathrm{C}-\mathrm{C}$ stretching absorbance, $v(\mathrm{C}-\mathrm{C})$ $[59,60]$. The ratio $v(\mathrm{C}-\mathrm{C}) / v(\mathrm{CN})$ has been shown to describe the state of hydrogen bonding on glutamine (Q), which is abundant in WG [50]. $v(\mathrm{C}-\mathrm{C}) / v(\mathrm{CN})$ is the same in both materials indicating that glutamines hydrogen bond similarly. The $1360 \mathrm{~cm}^{-1}$ absorbance is assigned to the $\mathrm{CH}_{3}$ symmetric deformation, $\delta_{\mathrm{s}}\left(\mathrm{CH}_{3}\right)$, and the $1410 \mathrm{~cm}^{-1}$ absorbance to the asymmetric $\mathrm{CH}_{3}$ deformation, $\delta_{\mathrm{as}}\left(\mathrm{CH}_{3}\right)$, on the side groups of the hydrophobic amino acids alanine (A), isoleucine (I), leucine (L), and valine (V) [59-61]. Abundant A, I, L, and V in WG are an important driving force for $\beta$-sheet formation and hydrophobic interactions drive higher scale self-assembly of protofibrils to large amyloid fibers $[47,48,50,52]$. Considering $\delta_{\mathrm{s}}\left(\mathrm{CH}_{3}\right)$ as a measure of up and down movement and $\delta_{\text {as }}\left(\mathrm{CH}_{3}\right)$ as a measure of side to side movement of the $\mathrm{CH}_{3}$ amino acid side groups, an increasing ratio $\delta_{\mathrm{s}}\left(\mathrm{CH}_{3}\right) / \delta_{\text {as }}\left(\mathrm{CH}_{3}\right)$ shows that $\mathrm{A}, \mathrm{I}, \mathrm{L}$, and $\mathrm{V}$ side groups are increasingly laterally constrained in $\beta$-sheets because they are more able to vibrate up and down relative to side to side. The $\beta$-sheet content of the two materials is similar, so differences in $\delta_{\mathrm{s}}\left(\mathrm{CH}_{3}\right) / \delta_{\text {as }}\left(\mathrm{CH}_{3}\right)$ must arise from hydrophobic interactions occurring outside of $\beta$-sheets [48, 52]. Hydrophobic interactions also drive protofibrils to aggregate into higher order fibrous structures so a decreased $\delta_{\mathrm{s}}\left(\mathrm{CH}_{3}\right) / \delta_{\text {as }}\left(\mathrm{CH}_{3}\right)$ for the $37^{\circ} \mathrm{C}$ composite relative to the $22^{\circ} \mathrm{C}$ material indicates that $\mathrm{CH}_{3}$ groups on the surface of the protofibrils interact end to end, resulting in a decreased $\delta_{\mathrm{s}}\left(\mathrm{CH}_{3}\right)$, to drive higher scale self-assembly to large amyloid fibers.

A final difference is that the area of the absorbance around $3250 \mathrm{~cm}^{-1}$ is larger in the $37^{\circ} \mathrm{C}$ composite. Increased hydrogen bonding of $\mathrm{OH}$ groups yields an increased absorbance area in 
this region [59]. OH groups originate in aspartic acid (D), glutamic acid (E), serine (S), threonine (T), and tyrosine (Y) although there is not much D and $\mathrm{E}$ and the amount of $\mathrm{OH}$ depends on the protonation of the acid. Wheat gluten is a mixture of the proteins gliadin ( $\mathrm{Gd}$, UniProt P04721, 0.49 mole fraction, 30,403 g/mol), high molecular weight glutenin $(\mathrm{GtH}$, UniProt P08488, 0.06 mole fraction, 70,867 g/mol), and low molecular weight glutenin (GtL, UniProt P10386, 0.45 mole fraction, 34,928 $\mathrm{g} / \mathrm{mol}$ ) and has about 13\% OH groups for hydrogen bonding. It is argued above that the fiber volume fraction, $\phi$ f, may be underestimated because the measured $37^{\circ} \mathrm{C}$ composite modulus would correspond to a composite with higher fiber content of $\mathrm{E}=2500 \mathrm{MPa}$ fibers. It is also possible that the increased hydrogen bonding in the $37^{\circ} \mathrm{C}$ composite over the $22^{\circ} \mathrm{C}$ material contributes to the increased modulus of the $37^{\circ} \mathrm{C}$ composite. This hydrogen bonding most likely occurs in the matrix phase because the properties of fibers produced at $37^{\circ} \mathrm{C}$ and $\mathrm{pH} 8$ in the absence of matrix have been measured repeatedly [47, 48]. A higher matrix modulus, $\mathrm{E}_{\mathrm{m}}$, in Equation $2 \mathrm{a}$ would result in a higher overall composite modulus, E, at a lower $\phi_{\mathrm{f}}$ than that predicted using the $\mathrm{E}_{\mathrm{m}}$ value reported in Fig. 4a. Using the measured $37^{\circ} \mathrm{C}$ composite modulus, $\mathrm{E}=266.39 \mathrm{MPa}$, fiber modulus, $\mathrm{E}_{\mathrm{f}}=2500 \mathrm{MPa}$, fiber volume fraction, $\phi_{\mathrm{f}}=0.002$, and matrix volume fraction, $\phi_{\mathrm{m}}=0.998$, in Equation $2 \mathrm{a}$ results in $\mathrm{E}_{\mathrm{m}}=261.92$ $\mathrm{MPa}$. This is 13.18 times higher than the measured matrix modulus at $22^{\circ} \mathrm{C}, \mathrm{E}_{\mathrm{m}}=19.87 \mathrm{MPa}$. The $37^{\circ} \mathrm{C}$ composite has an absorbance area at $3250 \mathrm{~cm}^{-1}$ that is 1.24 times higher than the $22^{\circ} \mathrm{C}$ material. Thus the hydrogen bonding in the matrix of the $37^{\circ} \mathrm{C}$ composite is 1.24 times that of the $22^{\circ} \mathrm{C}$ material. Assuming equal hydrogen bonding energies, material densities, and protein molecular weights for each material, the $24 \%$ more hydrogen bonding in the matrix of the $37^{\circ} \mathrm{C}$ material cannot result in a $1218 \%$ modulus increase. Therefore, a combination of 
underestimated $\phi_{\mathrm{f}}$ and increased $\mathrm{E}_{\mathrm{m}}$ in the $37^{\circ} \mathrm{C}$ composite seems likely for modulus discrepancy in predictions in Fig. 4a.

TGA weight loss (Fig. 6a) and first derivative of weight loss with temperature (dTGA, Fig. 6b) repeatedly show that the samples have different thermal stability. Around $130^{\circ} \mathrm{C}$, the $37^{\circ} \mathrm{C}$ composite has a faster weight loss than the $22^{\circ} \mathrm{C}$ material but the $22^{\circ} \mathrm{C}$ material has a second rapid weight loss at $172^{\circ} \mathrm{C}$. The $37^{\circ} \mathrm{C}$ composite contains more hydrogen bonding in the matrix and self-assembled fibers so absorbed water is loosely bound to the matrix relative to the $22^{\circ} \mathrm{C}$ material and releases quickly at $130^{\circ} \mathrm{C}$. The less structured $22^{\circ} \mathrm{C}$ material releases more tightly bound water at $172^{\circ} \mathrm{C}$, which does not exist in the much more structured $37^{\circ} \mathrm{C}$ composite. From $200^{\circ} \mathrm{C}$ to $450^{\circ} \mathrm{C}$, the $37^{\circ} \mathrm{C}$ composite is more thermally stable than the $22^{\circ} \mathrm{C}$ material, which has a much more rapid weight loss than the $37^{\circ} \mathrm{C}$ composite. Between $450^{\circ} \mathrm{C}$ and $500^{\circ} \mathrm{C}$, the $37^{\circ} \mathrm{C}$ composite has a more rapid weight loss but a higher ultimate degradation temperature of $460^{\circ} \mathrm{C}$ compared to $442^{\circ} \mathrm{C}$ for the $22^{\circ} \mathrm{C}$ material. The fibers and excess hydrogen bonding in the $37^{\circ} \mathrm{C}$ composite stabilize it at higher temperatures. By $460^{\circ} \mathrm{C}$, the $22^{\circ} \mathrm{C}$ material is much more degraded than the $37^{\circ} \mathrm{C}$ composite, which has one final rapid weight loss. Both materials maintain about $35 \%$ of their original weight at $600^{\circ} \mathrm{C}$. Wheat gluten is about $53 \%$ carbon. So it appears that the self-assembled WG materials are largely carbonized by $600^{\circ} \mathrm{C}$.

\section{Conclusions}

Hydrolyzing wheat gluten to low molecular weight proteins at $37^{\circ} \mathrm{C}$ and $\mathrm{pH} 8$ results in fully self-assembled fiber composites where some hydrolysis products self-assemble into high modulus fibers and the others serve as the matrix. Hydrolysis at $22^{\circ} \mathrm{C}$ and $\mathrm{pH} 8$ suppresses fiber formation resulting in just the matrix material. The chemical similarity between the fiber and matrix produces good fiber/polymer interactions as evidenced by SEM images and mechanical 
testing. Mechanical testing also shows that the $37^{\circ} \mathrm{C}$ composite has a higher flexural modulus and flexural breaking stress than the $22^{\circ} \mathrm{C}$ material. Both materials have similar $\beta$-sheet content and Q hydrogen bonding as determined by FTIR spectroscopy. However, the $37^{\circ} \mathrm{C}$ composite has a different state of hydrophobic groups on $\mathrm{A}, \mathrm{I}, \mathrm{L}$, and $\mathrm{V}$ and increased hydrogen bonding on OH groups. TGA shows that the $37^{\circ} \mathrm{C}$ composite is more thermally stable at higher temperatures than the $22^{\circ} \mathrm{C}$ material because of the increased intermolecular interactions and the presence of fibers.

\section{Acknowledgements}

Generous funding through NSF-CMMI-0856262, USDA-NIFA \#2010-65504-20429, the

Virginia Tech Institute for Critical Technology and Applied Science, and the Virginia Tech

Biodesign and Bioprocessing Research Center is greatly appreciated.

\section{References}

[1] Chawla KK. Composite Materials. New York: Springer-Verlag; 1987.

[2] Yano H, Yano H, Sugiyama J, Nakagaito AN, Nogi M. Optically transparent composites reinforced with networks of bacterial nanofibers. Advanced Materials.17(2):153-153.

[3] Askeland DR. The Science and Engineering of Materials. 3rd ed. Boston: PWS Pub.; 1994.

[4] Sperling LH. Introduction to Physical Polymer Science. 4th ed. Hoboken, N.J.: Wiley; 2006.

[5] Hull D, Clyne TW. An Introduction to Composite Materials. 2nd ed. Cambridge ; New York: Cambridge University Press; 1996.

[6] Mohanty AK, Misra M, Hinrichsen G. Biofibres, biodegradable polymers and biocomposites: An overview. Macromolecular Materials and Engineering. 2000;276277(1):1-24.

[7] Herrera-Franco PJ, Valadez-González A. Mechanical properties of continuous natural fibre-reinforced polymer composites. Composites Part A: Applied Science and Manufacturing. 2004;35(3):339-345.

[8] Hemsri S, Grieco K, Asandei AD, Parnas RS. Wheat gluten composites reinforced with coconut fiber. Composites Part A: Applied Science and Manufacturing. 2012;43(7):11601168 .

[9] Bhowmick M, Mukhopadhyay S, Alagirusamy R. Mechanical properties of natural fibrereinforced composites. Textile Progress. 2012;44(2):85-140.

[10] Barone JR. Polyethylene/keratin fiber composites with varying polyethylene crystallinity. Composites: Part A. 2005;36:1518-1524. 
[11] Barone JR. Lignocellulosic fiber-reinforced keratin polymer composites. Journal of Polymers and the Environment. 2009;17:143-151.

[12] Mohanty AK, Misra M, Drzal LT. Sustainable Bio-Composites from Renewable Resources: Opportunities and Challenges in the Green Materials World. Journal of Polymers and the Environment. 2002;10(1-2):19-26.

[13] Lodha P, Netravali A. Characterization of interfacial and mechanical properties of 'green' composites with soy protein isolate and ramie fiber. Journal of Materials Science. 2002;37:3657-3665.

[14] Song Y, Zheng Q, Liu C. Green biocomposites from wheat gluten and hydroxyethyl cellulose: Processing and properties. Industrial Crops and Products. 2008;28(1):56-62.

[15] Mohanty AK, Wibowo A, Misra M, Drzal LT. Effect of process engineering on the performance of natural fiber reinforced cellulose acetate biocomposites. Composites Part A: Applied Science and Manufacturing. 2004;35(3):363-370.

[16] Kunanopparat T, Menut P, Morel MH, Guilbert S. Reinforcement of plasticized wheat gluten with natural fibers: From mechanical improvement to deplasticizing effect. Composites Part A: Applied Science and Manufacturing. 2008;39(5):777-785.

[17] Wretfors C, Cho SW, Hedenqvist MS, Marttila S, Nimmermark S, Johansson E. Use of Industrial Hemp Fibers to Reinforce Wheat Gluten Plastics. Journal of Polymers and the Environment. 2009;17(4):259-266.

[18] Barone JR, Schmidt WF. Polyethylene reinforced with keratin fibers obtained from chicken feathers. Composites Science and Technology. 2005;65:173-181.

[19] Chabba S, Netravali A. 'Green' composites. Part I Characterization of flax fabric and gluteraldehyde modified soy protein concentrate composites. Journal of Materials Science. 2005;40:6263-6273.

[20] Huang X, Netravali A. Biodegradable green composites made using bamboo micro/nanofibrils and chemically modified soy protein resin. Composites Science and Technology. 2009;69(7-8):1009-1015.

[21] Zhang X, Do MD, Dean K, Hoobin P, Burgar IM. Wheat-Gluten-Based Natural Polymer Nanoparticle Composites. Biomacromolecules. 2007;8(2):345-353.

[22] Reddy N, Yang Y. Biocomposites developed using water-plasticized wheat gluten as matrix and jute fibers as reinforcement. Polymer International. 2011;60(4):711-716.

[23] Ye P, Reitz L, Horan C, Parnas R. Manufacture and Biodegradation of Wheat Gluten/Basalt Composite Material. Journal of Polymers and the Environment. 2006;14(1):1-7.

[24] Kunanopparat T, Menut P, Morel M-H, Guilbert S. Plasticized wheat gluten reinforcement with natural fibers: Effect of thermal treatment on the fiber/matrix adhesion. Composites Part A: Applied Science and Manufacturing. 2008;39(12):1787-1792.

[25] Barone JR, Schmidt WF, Liebner CFE. Compounding and molding of polyethylene composites reinforced with keratin feather fiber. Composites Science and Technology. 2005;65:683-692.

[26] Giannelis EP. Polymer Layered Silicate Nanocomposites. Advanced Materials. 1996;8(1):29-35.

[27] Knowles TPJ, Buehler MJ. Nanomechanics of functional and pathological amyloid materials. Nature Nanotechnology. 2011;6(8):469-479.

[28] MacPhee CE, Woolfson DN. Engineered and designed peptide-based fibrous biomaterials. Current Opinion in Solid State and Materials Science. 2004;8(2):141-149. 
[29] Castillo-Leon J, Anderson KB, Svendsen WE. Self-assembled peptide nanostructures for biomedical applications: Advantages and challenges. In: Pignatello R, editor. Biomaterials Science and Engineering, Rijeka, Croatia: InTech; 2011. p. 115-138.

[30] Davies RPW, Aggeli A, Boden N, McLeish TCB, Nyrkova IA, Semenov AN. Chapter 2 Mechanisms and Principles of 1D Self-Assembly of Peptides into $\beta$-Sheet Tapes. In: Rudy JK, editor. Advances in Chemical Engineering, vol. Volume 35: Academic Press; 2009. p. 11-43.

[31] Sunde M, Blake CC. From the globular to the fibrous state: protein structure and structural conversion in amyloid formation. Quarterly Reviews of Biophysics. 1998;31(1):1-39.

[32] Chiti F, Dobson CM. Protein misfolding, functional amyloid, and human disease. Annual Review of Biochemistry. 2006;75:333-366.

[33] Prusiner SB. Neurodegenerative Diseases and Prions. The New England Journal of Medicine. 2001;344(20):1516-1526.

[34] Barlow DE, Dickinson GH, Orihuela B, Kulp III JL, Rittschof D, Wahl KJ. Characterization of the adhesive plaque of the barnacle Balanus amphitrite: Amyloid-like nanofibrils are a major component. Langmuir. 2010;26(9):6549-6556.

[35] Gebbink MFBG, Claessen D, Bouma B, Dijkhuizen L, Wosten HAB. Amyloids-A functional coat for microorganisms. Nature Reviews Microbiology. 2005;3:333-341.

[36] Adamcik J, Berquand A, Mezzenga R. Single-step direct measurement of amyloid fibrils stiffness by peak force quantitative nanomechanical atomic force microscopy. Applied Physics Letters. 2011;98:193701.

[37] Adamcik J, Lara C, Usov I, Jeong JS, Ruggeri FS, Dietler G, et al. Measurement of intrinsic properties of amyloid fibrils by the peak force QNM method. Nanoscale. 2012;4(15):4426-4429.

[38] Ruggeri FS, Adamcik J, Jeong JS, Lashuel HA, Mezzenga R, Dietler G. Influence of the $\beta$ Sheet Content on the Mechanical Properties of Aggregates during Amyloid Fibrillization. Angewandte Chemie International Edition. 2015;54(8):2462-2466.

[39] Gazit E. Self-assembled peptide nanostructures: the design of molecular building blocks and their technological utilization. Chemical Society Reviews. 2007;32:1263-1269.

[40] Li C, Adamcik J, Mezzenga R. Biodegradable nanocomposites of amyloid fibrils and graphene with shape-memory and enzyme-sensing properties. Nature Nanotechnology. 2012;7(7):421-427.

[41] Li C, Bolisetty S, Mezzenga R. Hybrid Nanocomposites of Gold Single-Crystal Platelets and Amyloid Fibrils with Tunable Fluorescence, Conductivity, and Sensing Properties. Advanced Materials. 2013;25(27):3694-3700.

[42] Li C, Born A-K, Schweizer T, Zenobi-Wong M, Cerruti M, Mezzenga R. AmyloidHydroxyapatite Bone Biomimetic Composites. Advanced Materials. 2014;26(20):32073212.

[43] Oppenheim T, Knowles TPJ, Lacour SP, Welland ME. Fabrication and characterisation of protein fibril-elastomer composites. Acta Biomaterialia. 2010;6(4):1337-1341.

[44] Byrne N, Hameed N, Werzer O, Guo Q. The preparation of novel nanofilled polymer composites using poly(l-lactic acid) and protein fibers. European Polymer Journal. 2011;47(6):1279-1283.

[45] Rao SP, Meade SJ, Healy JP, Sutton KH, Larsen NG, Staiger MP, et al. Amyloid fibrils as functionalizable components of nanocomposite materials. Biotechnology Progress. 2012;28(1):248-256. 
[46] Athamneh A, Barone JR. Enzyme-mediated self-assembly of highly ordered structures from disordered proteins. Smart Materials and Structures. 2009;18:104024 (104028pp).

[47] Ridgley DM, Ebanks KC, Barone JR. Peptide Mixtures Can Self-Assemble into Large Amyloid Fibers of Varying Size and Morphology. Biomacromolecules. 2011;12(10):37703779.

[48] Ridgley DM, Claunch EC, Barone JR. The effect of processing on large, self-assembled amyloid fibers. Soft Matter. 2012;8(40):10298-10306.

[49] Ridgley DM, Barone JR. Evolution of the amyloid fiber over multiple length scales. ACS Nano. 2013;7(2):1006-1015.

[50] Ridgley DM, Claunch EC, Barone JR. Characterization of amyloid structures by FT-IR and Raman spectroscopy. Applied Spectroscopy. 2013;67(12):1417-1426.

[51] Ridgley DM, Freedman BG, Lee PW, Barone JR. Genetically encoded self-assembly of large amyloid fibers. Biomaterials Science. 2014;2(4):560-566.

[52] Ridgley DM, Claunch EC, Lee PW, Barone JR. The role of protein hydrophobicity in conformation change and self-assembly into large amyloid fibers. Biomacromolecules. 2014;15(4):1240-1247.

[53] Vincent J. Structural Biomaterials. Princeton: Princeton University Press; 1990.

[54] Tuck CS, Latham A, Lee PW, Barone JR. Wheat gluten plasticized with its own hydrolysate. Journal of Polymers and the Environment. 2014;22:430-438.

[55] Paparcone R, Buehler MJ. Failure of $A \beta(1-40)$ amyloid fibrils under tensile loading. Biomaterials. 2011;32(13):3367-3374.

[56] Keten S, Xu Z, Ihle B, Buehler MJ. Nanoconfinement controls stiffness, strength and mechanical toughness of $\beta$-sheet crystals in silk. Nature Materials. 2010;9(4):359-367.

[57] Esler WP, Stimson ER, Jennings JM, Vinters HV, Ghilardi JR, Lee JP, et al. Alzheimer's Disease Amyloid Propagation by a Template-Dependent Dock-Lock Mechanism. Biochemistry. 2000;39(21):6288-6295.

[58] Nguyen PH, Li MS, Stock G, Straub JE, Thirumalai D. Monomer adds to preformed structured oligomers of A $\beta$-peptides by a two-stage dock-lock mechanism. Proceedings of the National Academy of Sciences. 2007;104(1):111-116.

[59] Gunzler H, Gremlich H-U. IR Spectroscopy. Weinheim: Wiley-VCH; 2002.

[60] Barth A. The infrared absorption of amino acid side chains. Progress in Biophysics and Molecular Biology. 2000;74:141-173.

[61] Miyazawa T, Shimanouchi T, Mizushima S-i. Characteristic Infrared Bands of Monosubstituted Amides. The Journal of Chemical Physics. 1956;24(2):408-418. 


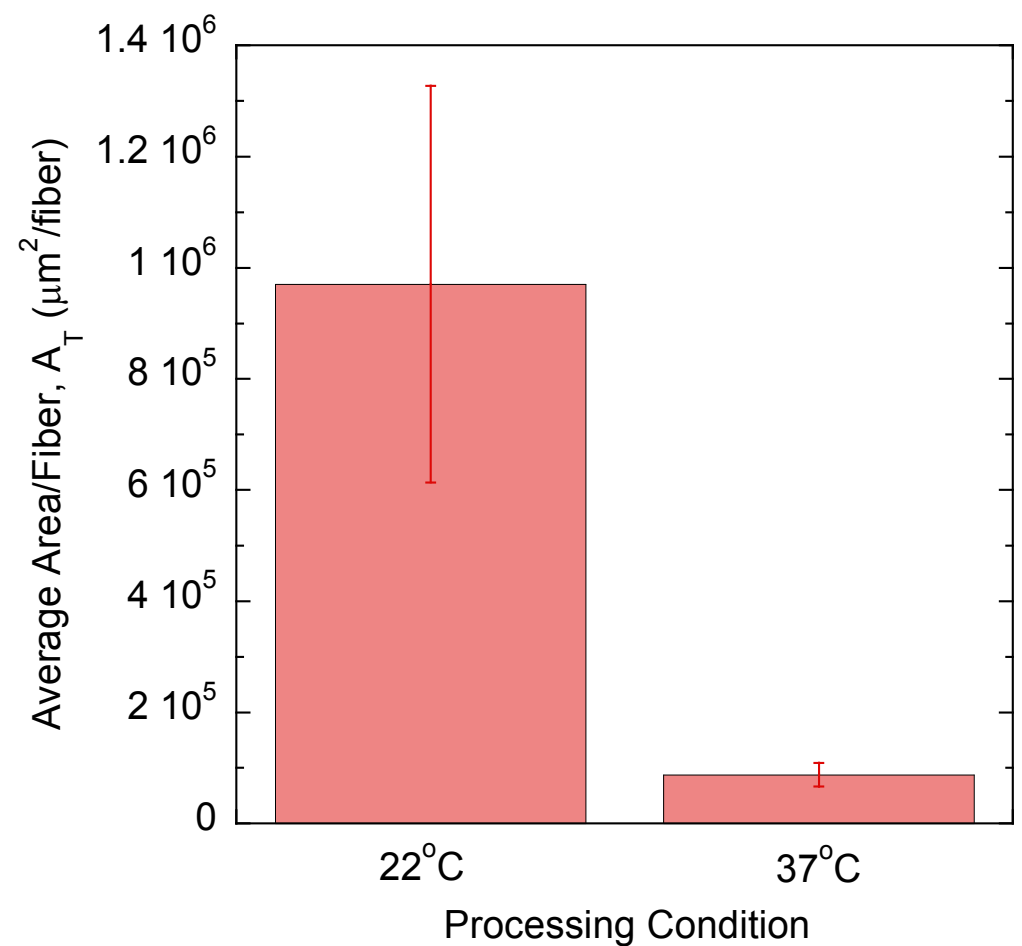

Figure 1. The average area surrounding each fiber, $\mathrm{AT}$, is low for materials formed at $37^{\circ} \mathrm{C}$ and this material is the fiber reinforced composite. At $22^{\circ} \mathrm{C}$, fiber self-assembly is suppressed and there are much less fibers per unit area observed. 

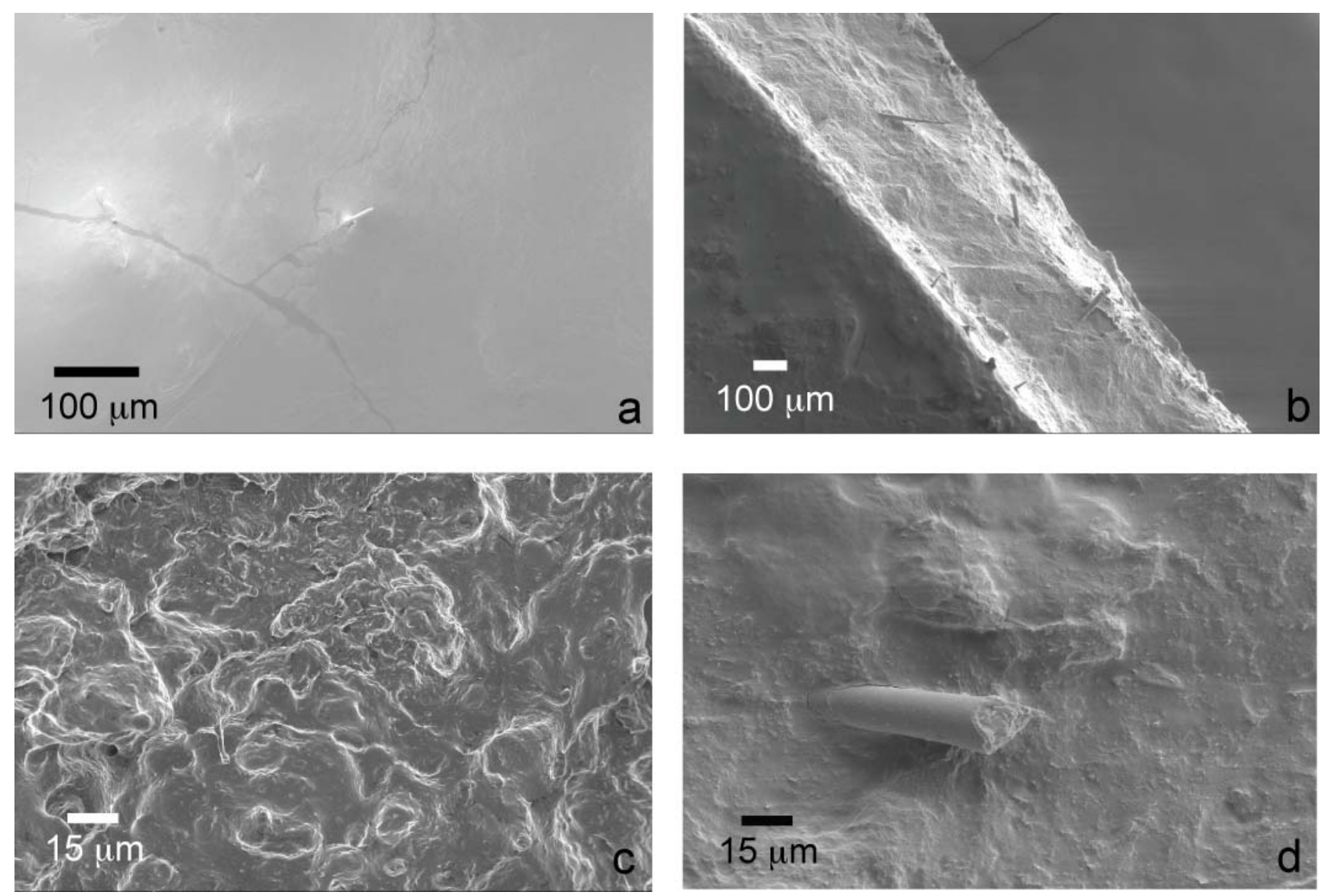

Figure 2. It is easier to observe fibers in the $3 \mathrm{~PB}$ sample edges for (a) $22^{\circ} \mathrm{C}$ material and (b) $37^{\circ} \mathrm{C}$ composite. Much less fibers per unit area are observed in the $22^{\circ} \mathrm{C}$ materials (a) than in the $37^{\circ} \mathrm{C}$ composites (b). $3 \mathrm{~PB}$ fracture surfaces of (c) $22^{\circ} \mathrm{C}$ materials and (d) $37^{\circ} \mathrm{C}$ composites show different behavior. $22^{\circ} \mathrm{C}$ materials fracture in a much more ductile manner than $37^{\circ} \mathrm{C}$ composites and much less fibers are observed in the $22^{\circ} \mathrm{C}$ material fracture surface. Self-assembled WG fibers are coated with matrix material and there are good fiber/polymer interactions (d). 


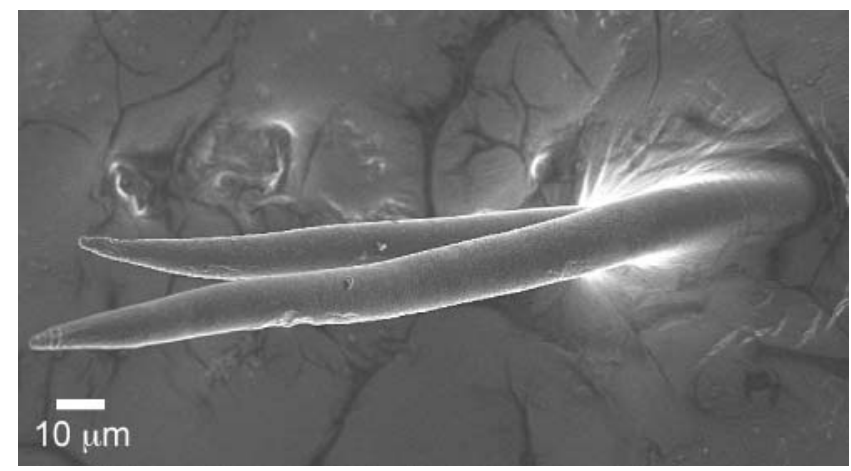

Figure 3. Observations of composite 3PB sample edges shows uncoated fibers have the dimensions and characteristic surface roughness of typical self-assembled WG fibers.
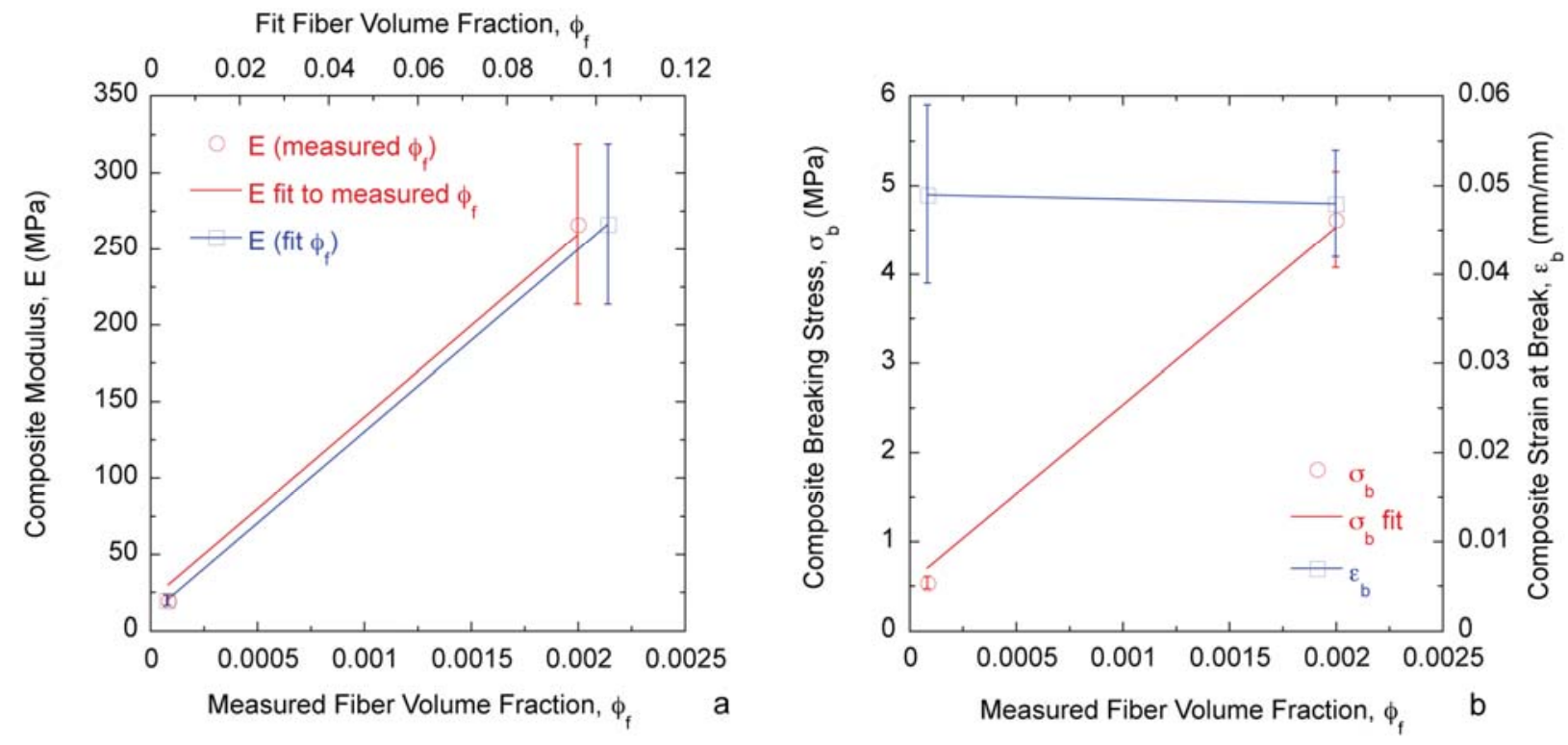

Figure 4. The larger amount of fibers in the $37^{\circ} \mathrm{C}$ composite results in a higher (a) modulus and (b) breaking stress. Fitting the fiber volume fraction to Equation 2a using the known composite, fiber, and matrix moduli results in a higher fiber volume fraction in the composite than is observed in SEM. 

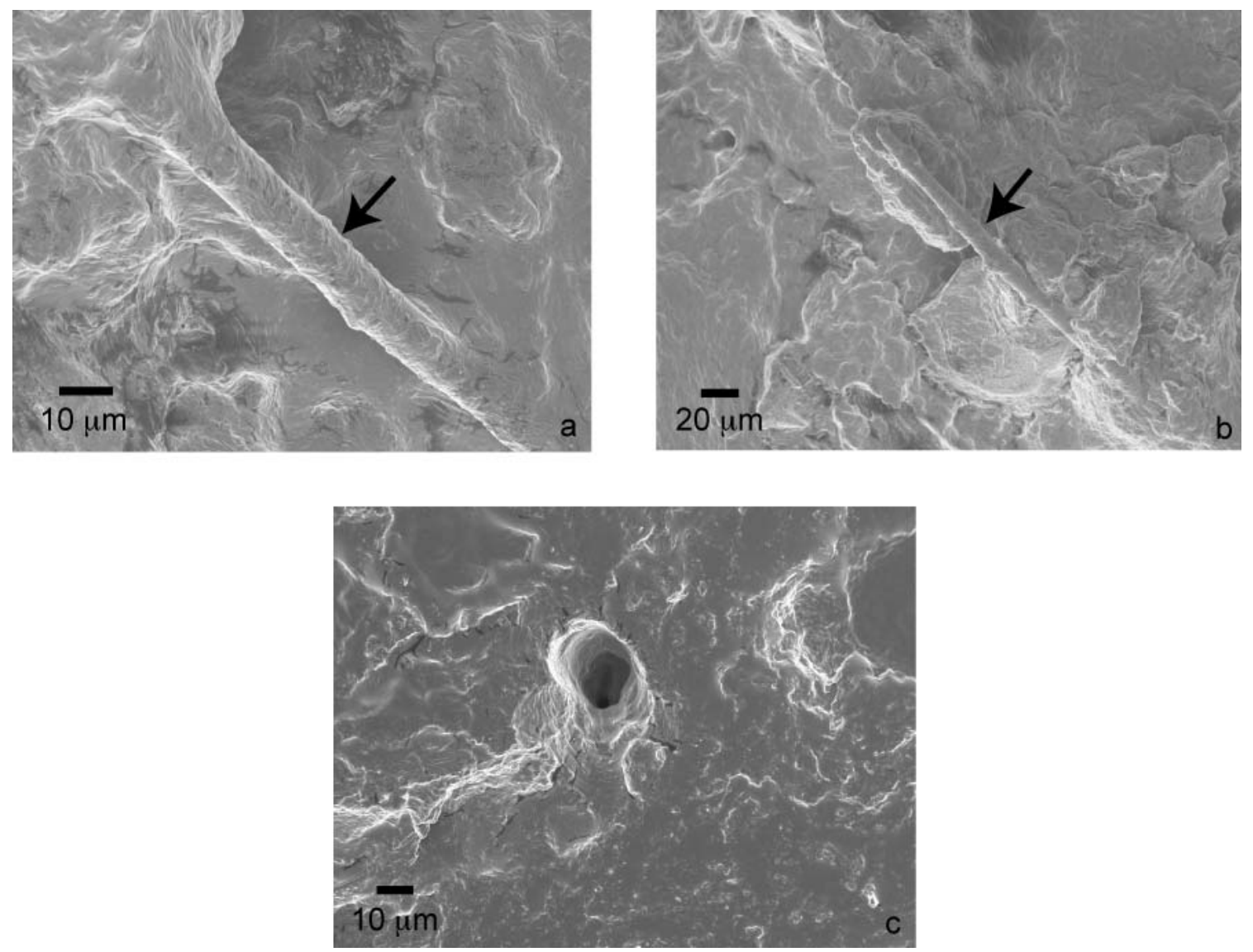

Figure 5. Observation of $37^{\circ} \mathrm{C}$ composite fracture surfaces show (a,b) fibers heavily coated with matrix material (indicated by arrows) are difficult to observe in the fracture surface. (c) Holes in the fracture surface are approximately the fiber diameter and are drawn out from the matrix, which could indicate pulled-out fibers during loading. 

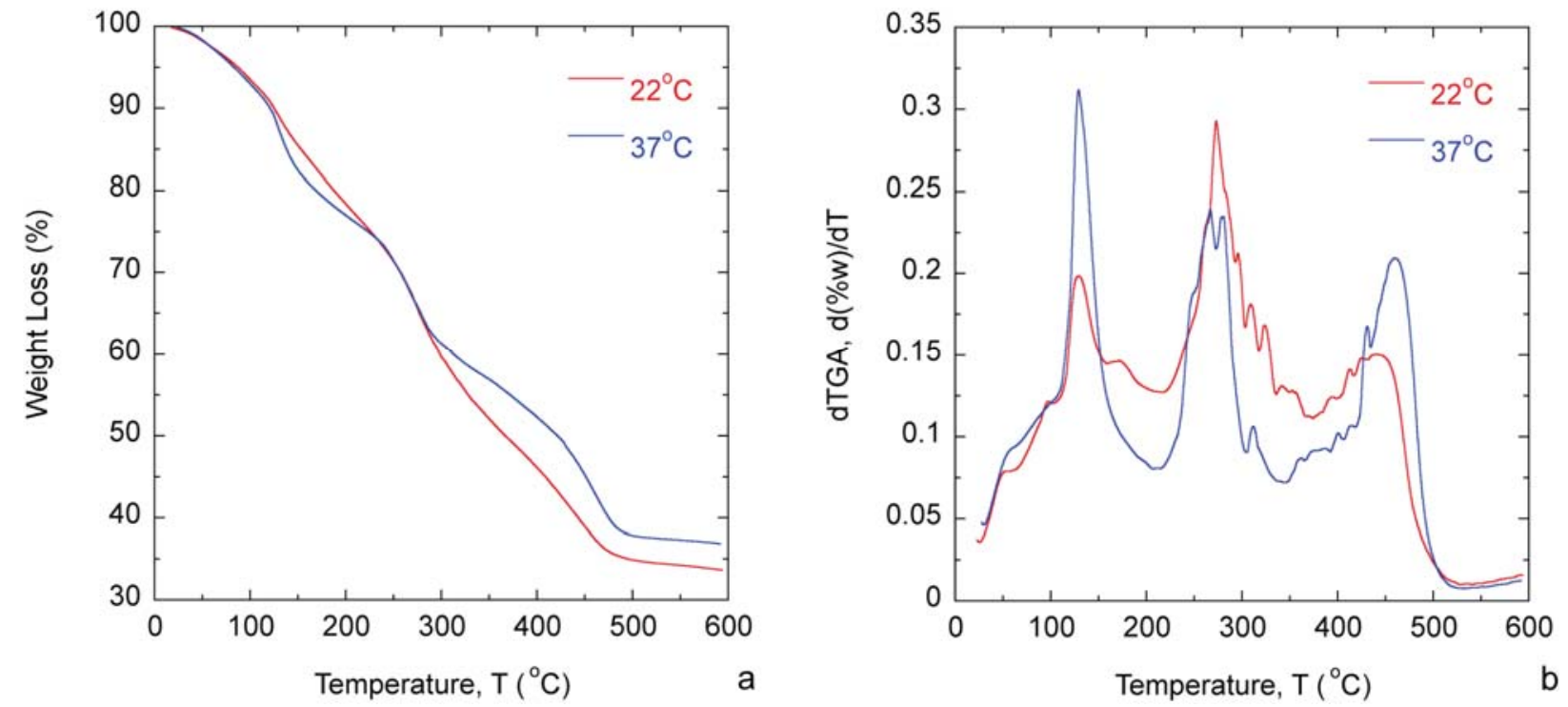

Figure 6. TGA (a) weight loss and (b) first derivative of weight loss with temperature (dTGA) results for a typical $22^{\circ} \mathrm{C}$ material and $37^{\circ} \mathrm{C}$ composite.

\section{Tables}

Table I. Measured mechanical properties of self-assembled materials.

\begin{tabular}{|c|c|c|c|}
\hline Material & $\mathbf{E} \mathbf{( M P a )}$ & $\sigma_{\mathbf{b}}(\mathbf{M P a})$ & $\boldsymbol{\varepsilon}_{\mathbf{b}}(\mathbf{m m} / \mathbf{m m})$ \\
\hline $22^{\circ} \mathrm{C}$ & $19.87 \pm 3.67$ & $0.54 \pm 0.07$ & $0.049 \pm 0.010$ \\
\hline $37^{\circ} \mathrm{C}$ & $266.39 \pm 52.67$ & $4.62 \pm 0.54$ & $0.048 \pm 0.006$ \\
\hline
\end{tabular}

Table II. FTIR analysis of self-assembled materials.

\begin{tabular}{|c|c|c|c|}
\hline Material & $\boldsymbol{v}(\mathbf{C}-\mathbf{C}) / v(\mathbf{C N})$ & $\delta_{\mathbf{s}}\left(\mathbf{C H}_{3}\right) / \delta_{\text {ass }}\left(\mathbf{C H}_{3}\right)$ & Area at $3250 \mathbf{~ c m}^{-1}$ \\
\hline $22^{\circ} \mathrm{C}$ & $1.14 \pm 0.02$ & $0.91 \pm 0.09$ & $451.76 \pm 72.64$ \\
\hline $37^{\circ} \mathrm{C}$ & $1.17 \pm 0.04$ & $0.52 \pm 0.03$ & $561.85 \pm 29.76$ \\
\hline
\end{tabular}

